\title{
Do First Generation Immigrant Adolescents Face Higher Rates of Bullying, Violence and Suicidal Behaviours Than Do Third Generation and Native Born?
}

\author{
Kevin Pottie · Govinda Dahal · Katholiki Georgiades • \\ Kamila Premji · Ghayda Hassan
}

Published online: 24 September 2014

(c) The Author(s) 2014. This article is published with open access at Springerlink.com

\begin{abstract}
We conducted a systematic review to examine first generation immigrant adolescents' likelihood of experiencing bullying, violence, and suicidal behaviours compared to their later-generation and native born counterparts, and to identify factors that may underlie these risks. Eighteen studies met full inclusion criteria. First generation immigrant adolescents experience higher rate of bullying and peer aggression compared to third generation and native counterparts. Refugee status and advanced parental age were associated with increased parent to child aggression among South East Asians. Family cohesion was associated with lower rates of violence. Suicidal ideation was lower across most immigrant adolescents' ethnicities, with the exception of Turkish and South Asian Surinamese female adolescents in the Netherlands. Bullying and peer aggression of immigrant children and adolescents and
\end{abstract}

K. Pottie $(\bowtie)$

Bruyere Research Institute, University of Ottawa, Ottawa, ON, Canada

e-mail: kpottie@uottawa.ca

K. Pottie - G. Dahal

Institute of Population Health, University of Ottawa, Ottawa,

ON, Canada

K. Pottie $\cdot$ K. Premji

Department of Family Medicine, University of Ottawa, Ottawa, ON, Canada

K. Georgiades

Department of Psychiatry and Behavioural Neurosciences,

Offord Centre for Child Studies, McMaster University,

Hamilton, ON, Canada

G. Hassan

Department of Psychology, University of Quebec at Montreal, Montreal, QC, Canada potential mitigating factors such as family cohesion warrant research and program attention by policymakers, teachers and parents.

Keywords Bullying · Peer aggression · Suicidal ideation - Intergenerational cultural dissonance . Acculturation - Immigrant adolescent health

\section{Introduction}

International migration has doubled over the past 30 years [1]. Each year, tens of millions of children and adolescents immigrate to new communities in new countries with or to join their parents [2]. With the risks of facing socioeconomic challenges, [3] as well as straining local resources and engendering anti-migrant sentiments, [2] this scale of migration has implications for the safety and security of immigrant adolescents, with adolescents defined here as aged $10-19$ years [4].

One example of risk to safety and security for immigrant adolescents is bullying and peer aggression. These forms of violence have emerged as particular concerns, with studies out of Australia, North America and Europe demonstrating risks to immigrant adolescents [5]. In one American qualitative study, more than $50 \%$ of Asian and South East Asian immigrant adolescents reported ethnic and racial tension and related peer aggression [6]. In immigration contexts, the parents' task in transmitting their values of origin becomes both more important and more difficult especially when the host culture's values are perceived as competing and more attractive to the adolescents [7, 17], with resulting intergenerational cultural dissonance. The losses inherent in migration are further compounded by what Robben [8] calls 'negative social mirroring,' which 
refers to the negative image of migrant groups that the majority may convey [9]. This may have implications for the identity and mental health of immigrant adolescents [10]. Victimized ethnic/racial minority adolescents are at risk for social anxiety and depressive symptoms [11, 12]. In the general population, several studies have shown an association between bullying and suicide-related behaviors, $[1,2,13-15]$ and a study found evidence consistent with a causal link, at least for girls [16, 17].

Immigrant adolescents may be particularly vulnerable to safety and security risks when there is conflict between familial and school or societal expectations [18]. In a study of Vietnamese and Cambodian immigrant adolescents in the U.S., such conflict indirectly predicted problem behaviours [18]. McQueen et al. [19] found similar results among Mexican-American adolescents, with family conflict aggravating the effects of acculturation on marijuana use and deviant behavior such as theft and engagement in violent activity.

Despite evidence demonstrating increased risk of immigrant adolescents to bullying, peer aggression, and mental health problems, there is little explicit information comparing the experiences of new immigrant adolescents with their later-generation counterparts [20-22]. Our review seeks to address this gap by examining the likelihood of new immigrant adolescents to experience bullying and peer aggression, other forms of violence (including parent-to-child aggression and sexual abuse), and suicidal behaviours. We also sought to identify potential moderators of these risks and variations across immigrant groups. We define first generation immigrant adolescents as those born in the country of cultural origin and who have immigrated with their parents to a new host country. Second generation immigrant adolescents are those born in the host country to at least one immigrant parent. Third generation immigrants are born in the host country to parents who were born in the host country. Our comparison groups were non-immigrant or third generation immigrant adolescents living in the same community [20-22].

This review aimed to address two research questions: Do first generation immigrant adolescents face a higher likelihood of bullying, aggression, and violence than their third generation or native born counterparts? Do first generation immigrant adolescents face a higher likelihood of suicide and suicidal ideation compared to third generation and native born counterparts?

\section{Methods}

The methodology for this systematic review was based on the six stage framework outlined by the Cochrane
Handbook for Systematic Reviews of Interventions [23]: (1) identifying the research question; (2) developing search protocol (3) identifying relevant studies based on search protocol; (4) study selection; (5) charting the data; (6) collecting, summarizing and reporting the results. In addition, we consulted immigrant parents from Latin American, Nepalese, Somali ethnic communities in Canada through Café Scientifique meetings to ensure relevancy of our selected outcomes. Concept mapping and synonym listing was prepared based on Population (immigrant and refugee adolescents, and family), Exposure (experiences of acculturation, cultural discordance (differences related to language, cultural beliefs, and religious beliefs), and/or intergenerational cultural dissonance (conflict between parent and adolescent over cultural values), Comparison (versus non-immigrant and later generation immigrants and native born adolescents), and Outcomes (based on the literature identified in our Introduction: bullying, peer aggression, physical or sexual violence, and suicide or suicidal ideation).

\section{Search and Selection}

A sensitive search of electronic bibliographic databases was performed to retrieve all articles combining the concepts of cultural discordance, immigrant and refugee children and adolescents, and safety and security. The search strategy was devised on Ovid Medline and then adapted for other databases. Without limiting by language, we identified studies by searching the Cochrane Library, Medline, Global Health, Health and Safety Science Abstracts, HealthStar, Scopus, PsychInfo, and Social Science Abstracts. In addition, we conducted a sensitive search using the term "intergenerational cultural dissonance." In all cases, the databases were searched from inception to Oct 31, 2011, and an updating Medline search for new studies with comparison groups was conducted on July 1, 2013. All references were imported into an EndNote Library and tagged with the name of the database. Duplicates were removed within EndNote, leaving the final total of results at 2,274 (2,270 from the electronic databases and 4 from other sources).

Two reviewers independently screened titles and abstracts of all 2,274 studies, applying inclusion and exclusion criteria and identifying relevant articles. Inclusion criteria included observational designs, a sample of greater than 100 participants, and reporting on our outcome variables and our target populations: immigrant adolescents aged 10-19 years and with a comparison population to third generations or native born adolescents. Discrepancies were resolved by consensus. However, if consensus could not be made between two reviewers, a third party 


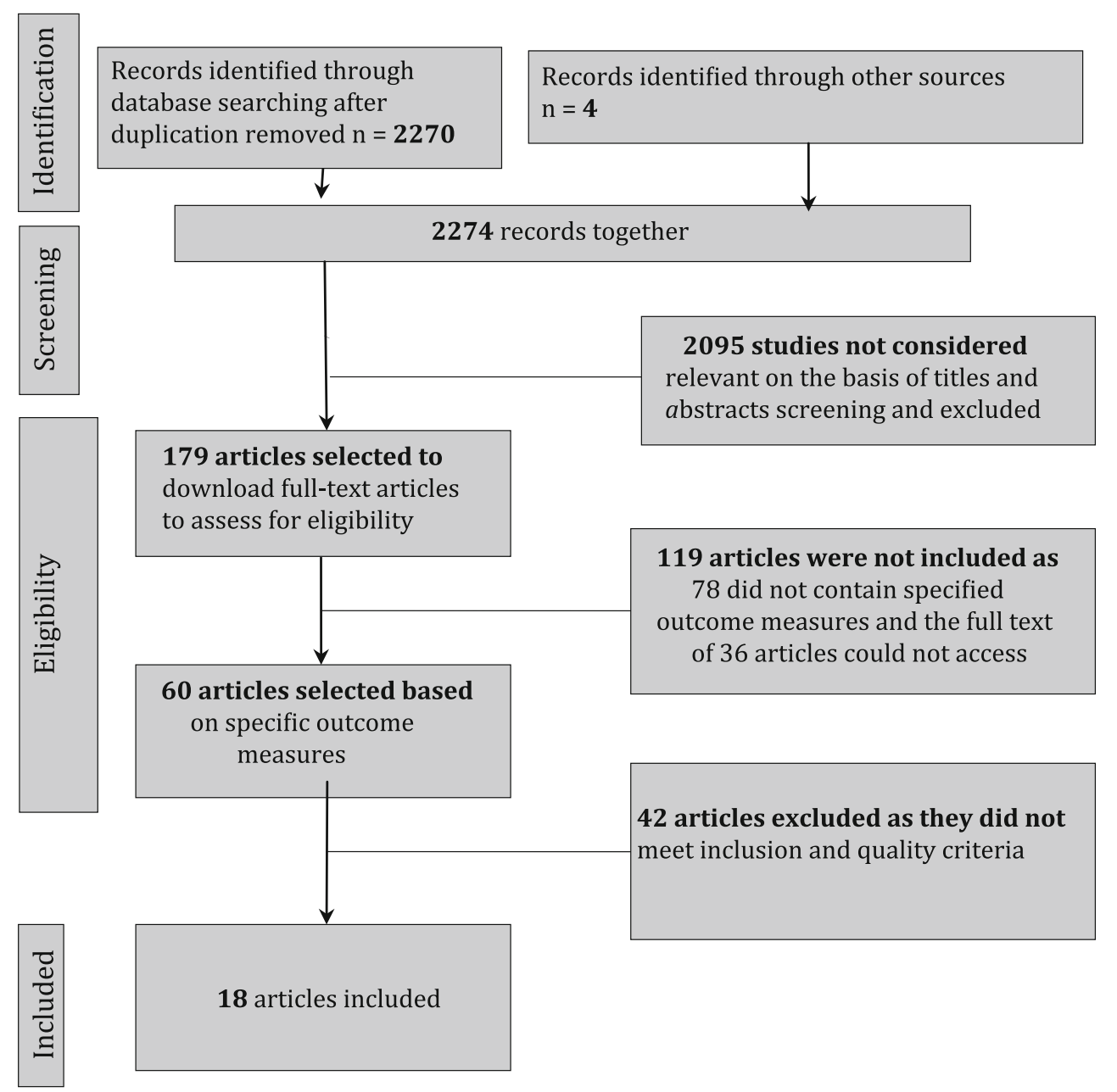

Fig. 1 PRISMA flow diagram

expert was involved for tiebreaking. This occurred in only three instances.

Papers which met criteria were then subject to a full text review. To ensure scientific quality, we appraised the studies using the Newcastle Tool for Observation Studies [24] (see Table 3 in Appendix).

\section{Certainty of Effect Assessment}

Two reviewers independently appraised and extracted details of the selected articles using standardised abstraction forms, and resolved discrepancies by consensus. A final quality assessment of all selected studies was conducted using the GRADE (Grading of Recommendations Assessment, Development and Evaluation) approach [25]. We report the quality rating for outcomes in the results. We used a narrative synthesis method to integrate related findings into descriptive summaries [23]. The reporting of the search and selection results followed the PRISMA principles (Preferred Reporting Items for Systematic Reviews and Meta-Analyses) [26].

\section{Results}

Data Collection and Study Characteristics

A flow diagram (Fig. 1) shows the identification, screening, eligibility assessment, and inclusion of studies in the systematic review. Of the initial 2,274 studies, 179 met our criteria for full appraisal. After repeated appraisals, 18 studies met full inclusion criteria.

Of the 18 studies, a majority were carried out in the USA (14 studies), followed by the Netherlands ( 2 studies), France (1 study), and Israel (1 study). All studies examined immigrant adolescents where there was a difference in primary language and culture from the local non-immigrant community. There were a total of 41,476 participants 
Table 1 Characteristics of included studies

\begin{tabular}{|c|c|c|c|c|}
\hline Study & Study design & Country & Participants & Outcomes measured \\
\hline $\begin{array}{l}\text { Altschul } \\
\text { and Lee } \\
{[35]}\end{array}$ & Longitudinal & USA & $\begin{array}{l}\text { Total } \mathrm{n}=845 \text { Hispanic mothers of preschool } \\
\text { aged children } \\
\text { Foreign-born }=328 \\
\text { Native US born }=517 \\
\text { (Age of mothers not specified) }\end{array}$ & $\begin{array}{l}\text { Maternal physical aggression directed toward } \\
\text { young children }\end{array}$ \\
\hline $\begin{array}{l}\text { Cho and } \\
\text { Haslam } \\
{[40]}\end{array}$ & Cross sectional & USA & $\begin{array}{l}\text { Total } n=227 \text { adolescents } \\
\text { Korean immigrants to US }=62 \\
\text { Korean students living in Korea }=47 \\
\text { Non-Korean-American students living in the } \\
\text { US }=31 \\
\text { Mean age }=16.6 \text { years }(\mathrm{SD}=1.1) \\
\text { Girls }=129 \text { and Boys }=98\end{array}$ & $\begin{array}{l}\text { Relationship between acculturative stress, } \\
\text { social support and suicide- related } \\
\text { phenomena among adolescent immigrants in } \\
\text { the US }\end{array}$ \\
\hline $\begin{array}{l}\text { Decker } \\
\text { et al. [37] }\end{array}$ & Cross-sectional & USA & $\begin{array}{l}\text { Total } \mathrm{n} \text { considered for analysis }=5,919 \text { high } \\
\text { school girls, } \\
\text { White }=76 \% \text {, Hispanic } 10 \% \text {; Black } 7 \% \text {; } \\
\text { Asian } 3 \% \text {; Others } 2 \% ; \\
\text { Age }=14 \text { years or younger }(12 \%), 15 \text { years } \\
(26 \%), 16 \text { years }(26 \%), 17 \text { years }(23 \%) \text {, } \\
18 \text { years and above }(14 \%) ; \\
\text { Immigrants }=13 \%\end{array}$ & Immigrant status and sexual assault \\
\hline Fuligni [33] & $\begin{array}{l}\text { Both cross- } \\
\text { sectional and } \\
\text { longitudinal }\end{array}$ & USA & $\begin{array}{l}\text { Total } \mathrm{n}=998 \text { students; Longitudinal }=353 \\
\text { and Cross sectional }=645 ; \text { Sample from: } \\
\text { Mexican }=168(52 \% \text { girls }) \\
\text { Chinese }=148(56 \% \text { girls }) \\
\text { Filipino }=403(51 \% \text { girls }) \\
\text { European }=279(51 \% \text { girls }) ; \\
\text { Mean age range }=12.1-15.2 \text { years })\end{array}$ & $\begin{array}{l}\text { Adolescent's beliefs, expectations, and } \\
\text { relationships with parents on the basis of } \\
\text { parental authority and individual autonomy. }\end{array}$ \\
\hline $\begin{array}{l}\text { Juang and } \\
\text { Alvarez } \\
{[34]}\end{array}$ & Cross-sectional & USA & $\begin{array}{l}\text { Total } n=309 \text { Chinese American students } \\
\quad(63 \% \text { girls }) \\
\text { US born }=66 \% \\
\text { Foreign born- } 29 \% \\
\text { Grew-up with both parents }=89 \% \\
\text { Age range }=13-17 \text { years }\end{array}$ & $\begin{array}{l}\text { Perceived discrimination with family conflict } \\
\text { and family cohesion }\end{array}$ \\
\hline Kim et al. & Cross sectional & USA & $\begin{array}{l}\text { Total } n=444 \text { Chinese American families } \\
\text { Girls }=226 ; \text { Boys }=218 \\
\text { Age range }=12-15 \text { years }\end{array}$ & $\begin{array}{l}\text { Testing that generational dissonance may } \\
\text { indicate a family context that places children } \\
\text { at increased risk for adverse outcomes such } \\
\text { as acculturation, parenting, adolescent } \\
\text { depressive symptoms, discrimination, SES } \\
\text { and mother's and father's length of stay in } \\
\text { the U.S. }\end{array}$ \\
\hline $\begin{array}{l}\text { Lau et al. } \\
\text { [27] }\end{array}$ & Cross-sectional & USA & $\begin{array}{l}\text { Total } \mathrm{n}=1,293 \text { Asian American parents of } \\
18 \text { years and older who had at least one child } \\
\text { (sex distribution of sample population not } \\
\text { reported) }\end{array}$ & $\begin{array}{l}\text { Minor assault (pushed, grabbled, or shoved; } \\
\text { threw something at; slapped, hit or spanked) } \\
\text { Severe assault (kicked, bit, or hit with fist; } \\
\text { beat up; choked; burned or scalded) }\end{array}$ \\
\hline $\begin{array}{l}\text { Le and } \\
\text { Stockdale } \\
{[28]}\end{array}$ & Cross Sectional & USA & $\begin{array}{l}\text { Total } \mathrm{n}=329 \text { Chinese and Southeast Asian } \\
\text { youth; Cambodian }=120 ; \text { Chinese }=64 ; \\
\text { Lao/Mien }=67 ; \text { and Vietnamese }=86 \text {; } \text { Age } \\
\text { range }=10-18 \text { years old; Gender-fairly } \\
\text { equally distributed. }\end{array}$ & $\begin{array}{l}\text { Acculturative dissonance, ethnic identity, peer } \\
\text { delinquency, and serious violence }\end{array}$ \\
\hline $\begin{array}{l}\text { Molnar } \\
\text { et al. [32] }\end{array}$ & $\begin{array}{l}\text { Longitudinal } \\
\text { (cohort) }\end{array}$ & USA & $\begin{array}{l}\text { Total } \mathrm{n}=8,872 \text { residents from African } \\
\text { American, Non-Hispanic White, and } \\
\text { Hispanic } \\
\text { Age: } 3-15 \text { years } \\
\text { Gender }=\text { boys } 50 \% \text {, Girls } 50 \%\end{array}$ & $\begin{array}{l}\text { Correlation between neighbourhoods and the } \\
\text { incidence of parent-to-child physical } \\
\text { aggression }\end{array}$ \\
\hline
\end{tabular}


Table 1 continued

\begin{tabular}{|c|c|c|c|c|}
\hline Study & Study design & Country & Participants & Outcomes measured \\
\hline $\begin{array}{l}\text { Peguero } \\
\text { [31] }\end{array}$ & Longitudinal & USA & $\begin{array}{l}\text { Total } \mathrm{n}=1,457 \text { Public Latino students; Boys } \\
48.5 \% \text { and Girls } 51.5 \% \text {; Age range- not } \\
\text { specifically mentioned; } \\
\text { First generation immigrant } 27.9 \% \\
\text { Second generation immigrant } 40.8 \% \text { and } \\
\text { Third generation immigrant } 31.3 \%\end{array}$ & $\begin{array}{l}\text { Role of immigrant status and English } \\
\text { proficiency for Latino students' experiences } \\
\text { with school violence: (1) property } \\
\text { victimization (2) Violent (3) Fear (feel } \\
\text { unsafe), and (4) Formal disciplinary school } \\
\text { sections (suspended/put on propagation, and } \\
\text { transfer to school from disciplinary reasons }\end{array}$ \\
\hline $\begin{array}{l}\text { Pena et al. } \\
\text { [38] }\end{array}$ & Longitudinal & USA & $\begin{array}{l}\text { Total } \mathrm{n}=3,135 \text { Latino adolescents of } \\
16 \text { years where } 50 \% \text { were females. Of total } \\
\text { sample, } 25.3 \% \text {, comes from 1st generation } \\
40.9 \% \text { from } 2 \text { nd and } 33.8 \% \text { from 3rd } \\
\text { generation } \\
\text { Mexican-American } 49.9 \% \text { Puerto Rican } \\
17.8 \% \text {, Cuban-American } 15.8 \% \text {, Other } \\
\text { Hispanics } 16.5 \%\end{array}$ & $\begin{array}{l}\text { Relation between suicide attempts and } \\
\text { immigrant generation status, also measured } \\
\text { predicted risk factors associated with } \\
\text { elevated suicide behaviours, namely } \\
\text { substance use, problematic alcohol use, and } \\
\text { depressive symptoms. }\end{array}$ \\
\hline $\begin{array}{l}\text { Ponizovsky } \\
\text { and } \\
\text { Ritsner } \\
{[41]}\end{array}$ & Cross sectional & Israel & $\begin{array}{l}\text { Total } \mathrm{n}=406 \text { Jewish immigrant adolescent to } \\
\text { Israel and native-born Jewish } \\
\text { Age }=11-18 \text { years } \\
\text { Male sample } 51.3 \% \text {; } \\
\text { Mean age of respondents } 14.5 \text { (SD 2,1 years) }\end{array}$ & $\begin{array}{l}\text { Examine suicidal ideation and suicide } \\
\text { attempts, behaviour problems, psychological } \\
\text { distress, social support, and adjustment } \\
\text { difficulties in a sample of adolescent }\end{array}$ \\
\hline $\begin{array}{l}\text { Peguero } \\
\text { [30] }\end{array}$ & $\begin{array}{l}\text { Longitudinal } \\
\text { (Multivariate } \\
\text { regression } \\
\text { analysis) }\end{array}$ & USA & $\begin{array}{l}\text { Total } \mathrm{n}=8,383 \text { students } \\
\text { Latino 1,628, Asian American 1,129, and white } \\
\text { American 5,626; } \\
\text { 1st generation } 28 \%, 2 \text { nd generation } 41 \% \text { and } \\
\text { 3rd plus generation } 31 \% \text {; } \\
\text { Female } 52 \% \text {, but age is not specifically } \\
\text { mentioned. }\end{array}$ & $\begin{array}{l}\text { Pattern of victimization in schools, in part } \\
\text { based on immigrant generation }\end{array}$ \\
\hline $\begin{array}{l}\text { Spencer and } \\
\text { Le [29] }\end{array}$ & Cross Sectional & USA & $\begin{array}{l}\text { Total } n=329 \\
\text { Cambodian }=120 \text { of } 15 \text { years } \\
\text { Chinese }=64 \text { of } 14 \text { years } \\
\text { Lao/Mien }=67 \text { of } 15 \text { years } \\
\text { Vietnamese }=86 \text { of } 14 \text { years } \\
\text { In all samples, the ratio of males and females } \\
\text { fairly equally distributed }\end{array}$ & $\begin{array}{l}\text { Peer delinquency, parental engagement, } \\
\text { serious violence and family/partner violence }\end{array}$ \\
\hline $\begin{array}{l}\text { Van Bergen } \\
\text { et al. [39] }\end{array}$ & Longitudinal & Netherlands & $\begin{array}{l}\text { Total } \mathrm{n}=4,527 \text { of young females } \\
\text { Dutch }=3,090 \\
\text { Moroccan }=557 \\
\text { Turkish }=614 \\
\text { Suriname }=266 \\
\text { Age }=14-16 \text { years }\end{array}$ & $\begin{array}{l}\text { The prevalence of non-fatal suicidal behaviour } \\
\text { of the sampled population and examines risk } \\
\text { factors in non-western female immigrant } \\
\text { adolescents compared to majority female } \\
\text { adolescents }\end{array}$ \\
\hline $\begin{array}{l}\text { Van Bergen } \\
\text { et al. [65] }\end{array}$ & Longitudinal & Netherlands & $\begin{array}{l}\text { Total } n=249 \text { Turkish adolescents } \\
\text { Age }=12-18 \text { years } \\
\text { Female sample } 53 \% \\
\text { Male } 47 \%\end{array}$ & $\begin{array}{l}\text { The prevalence of suicidal ideation and the } \\
\text { vulnerability across several ethnic minorities } \\
\text { versus ethnic majority adolescents } \\
\text { Also examine whether ethnic minority } \\
\text { adolescents are at risk for suicidal ideation } \\
\text { because of a family background of migrants, } \\
\text { social-economic position and certain family } \\
\text { factors - influence psychological } \\
\text { constellations. }\end{array}$ \\
\hline $\begin{array}{l}\text { Van } \\
\text { Leeuwen } \\
{[56]}\end{array}$ & Cross sectional & France & $\begin{array}{l}\text { Total } n=292 \text { students } \\
\text { French high school girls }=122 ; \text { French high } \\
\text { school boys }=170 \\
\text { Age }=15-21 \text { years }\end{array}$ & $\begin{array}{l}\text { Role of acculturation in suicidal ideation } \\
\text { among second generation immigrant } \\
\text { adolescents in France }\end{array}$ \\
\hline
\end{tabular}


Table 1 continued

\begin{tabular}{|c|c|c|c|c|}
\hline Study & Study design & Country & Participants & Outcomes measured \\
\hline $\begin{array}{l}\text { Ying and } \\
\text { Han [42] }\end{array}$ & Longitudinal & USA & $\begin{array}{l}\text { Total n }(\text { wave } 1)=5,262 \text { adolescents } \\
\text { Total n (wave } 2)=4,288 \text { adolescents } \\
\text { Vietnamese } 48.4 \% \\
\text { Laotian } 26.3 \% \\
\text { Cambodian } 16.5 \% \\
\text { Hmong } 8.8 \% \\
\text { Males } 50.4 \% \text { and Females } 49.6 \%\end{array}$ & $\begin{array}{l}\text { Intergenerational conflict and depressive } \\
\text { symptomatology }\end{array}$ \\
\hline
\end{tabular}

across the 18 studies and approximately $65 \%$ of participants were females (Table 1).

\section{Bullying, Peer Aggression and Violence}

Eight U.S.-based studies (four cross sectional and four prospective cohort) examined immigrant status and its associations with victimization, dating violence, school violence, parent-to-adolescent physical aggression, peer discrimination and harassment, violence, and sexual violence.

First generation immigrant adolescents from non-English speaking countries reported more episodes of bullying and violence at school than did non-immigrant adolescents. This was noted among Cambodian, Chinese, Lao/Mien and Vietnamese [27-29], Latino [30-32], and Filipino [33] populations. First generation Latino students were more likely to report being a victim of violence than third generation (English speaking) Latino students $(p<0.001)$ [31]. Discrimination was associated with loneliness, anxiety and somatization, but among Chinese populations, immigrant family cohesion buffered the negative effects of discrimination [34].

First generation Latino American immigrant adolescents were more likely to feel unsafe at school than later generation Latinos [31]. There was a strong positive association between students feeling safe in their learning environments and educational success among Latino and Asian first generation immigrant adolescents; the third generation adolescents of immigrant origin usually reported feeling safer than their first generation counterparts but less so than their White counterparts [30].

First generation Latin immigrant mothers demonstrated lower rates of parent-to-adolescent aggression than did native born Latin American mothers. Immigrant status reduced risk, while maternal alcohol use, parenting stress, and child aggression emerged as the strongest risk factors for maternal physical aggression [35]. Chicago neighbourhoods with greater concentrations of immigrants, independent of the characteristics of immigrant families, had a lower rate of parent to adolescent aggression [32]. Parents' refugee status, however, was associated with increased family violence in another study of South Asian adolescents [29]. Older parental age was associated with severe parent to adolescent aggression in one Asian American immigrant study (OR 1.08; $p<0.05$ ) [27]. In a Korean American study, risk for parent-adolescent physical aggression from immigrant mothers was found to increase when the immigrant mothers themselves experienced high acculturation conflict and discrimination in host societies [36].

In the U.S., first generation immigrant girls who were black adolescents or sexually active Hispanics experienced higher rates of sexual assault among age and ethnic/racial groups [37]. Acculturation did not seem to impact risk of sexual victimization [37].

\section{Suicide and Suicidal Ideation}

Eight studies (four cross sectional studies and four prospective cohort studies) examined suicide and suicidal ideation among immigrant adolescents. These studies measured acculturation stress, depression or depressive symptoms, distress, social and attention problem, academic performance, suicidal ideation, and suicide attempts among immigrant adolescents.

In a U.S. national survey of more than 20,000 Latino American adolescents/adolescents, suicide attempts were less likely among first generation Latino Americans, with second generation Latinos having a higher RR at 2.87 (95\% CI 1.34-6.14) and third generations having the highest likelihood with a RR 3.57 [38]. These findings of lower rates of suicidal ideation and fewer suicide attempts among earlier generations were also found in studies examining Korean American [39, 40], Latin American [41], Russian Israeli [38], and Moroccan Dutch [39] immigrant adolescents. Notable exceptions were South Asian-Surinamese and Turkish female immigrant adolescents in the Netherlands, who experienced a higher rate of suicide attempts (19.2 and $14.8 \%$ respectively) than non- 
immigrant Dutch adolescents $(9 \%)$ and Moroccan immigrant adolescents $(6.2 \%)$ [39].

Mitigating and aggravating factors for suicidal ideation and suicide were also identified. In the U.S., perceived child-parent discrepancy in preference for American ways significantly predicted intergenerational cultural dissonance $(\beta=0.27 ; p=0.05)$, and this conflict in acculturation during early adolescence predicted increased depressive symptomatology in late adolescence [42]. In a Korean immigrant study from the U.S., acculturation stress was associated with increased psychological symptoms $(p<0.047)$ and suicidal ideation $(p<0.01)$ [32]. Among these adolescents, living in an intact family was associated with markedly better outcomes with respect to suicidal ideation than when a family was geographically separated [40]. In a Chinese American immigrant study, a high discrepancy in father to adolescent acculturation levels was associated with significantly more adolescent depressive symptoms, as was unsupportive father to adolescent relationships. The sample included slightly more daughters than sons. Adolescent reports of parental warmth are associated with less depressive symptoms $(p<0.001)$ [43] (Table 2).

\section{Discussion}

To our knowledge, this study is the first international systematic review examining the effect of generational status on violence and suicidal behaviours experienced by immigrant children and adolescents. Previous reviews examining such outcomes have focused more on aspects of criminality and delinquency [44].

We found that across many immigrant groups, bullying and peer aggression were consistently significantly higher for non-official language speaking first generation immigrant adolescents compared to third generation and native born adolescents. This suggests that risks related to violence are greater when an immigrant adolescent speaks a language other than the primary language of the host country. This highlights a distinct sensitive period during migration $[45,46]$ that demands ongoing research to disaggregate data on socioeconomic status, gender, and ethnicity. Aggravating factors may include high academic standing [47], while alleviating factors may include safe schools [48], ethnic diversity within schools [49, 50], and family cohesion [34]. These findings seem to reflect previously proposed frameworks within which intergenerational cultural dissonance contributes to the violence experienced by immigrant adolescents [27, 34]. Immigrant parents are faced with the challenge of ensuring the continuity and transmission of their cultural heritage, while simultaneously promoting their adolescents' integration into the host culture. However, when both cultural environments, family cultural of origin and host culture promote conflicting values, the result may be increased intergenerational cultural dissonance, family conflict and increased risk for violence [17, 51, 52]. Scholars' have encouraged immigrant parents' to transmit their cultural values of origin, as a protective factor [53]. Conversely, undermining immigrant parents' transmission of values may contribute to a rise of family conflict and adolescent difficulties.

Studies in the general population have associated bullying with health related symptoms [54], and likewise, in immigrant populations, peer aggression and ethnic bullying have been repeatedly associated with negative repercussions for mental health [16]. However, efforts to study immigrant adolescent health outcomes internationally are just beginning [55]. Although immigrant adolescents are very heterogeneous both within and across countries, the process of facing discrimination and adapting to new cultural, language and other norms includes shared commonalities.

Immigrant adolescents appeared to benefit from cohesive families, and despite evidence for acculturation stress and family intergenerational cultural dissonance, suicidal behaviour rates remained low among immigrant adolescents, and lower among first generation immigrant adolescents than their later generation counterparts. Immigrant adolescents who are not living together with their biological parents experience a higher level of life stress and suicidal thoughts than their counterparts living with intact families [32]. Repeated use of drugs other than marijuana and alcohol may be another potential mediator of generation status on suicide attempts [30], as might low socioeconomic status and poor academic performance [56]. Among South Asian-Suriname and Turkish adolescent girls in Holland, it appeared that uncommonly high rates of violence within the families may have played a significant role in a higher risk of suicidal behaviours among this population [39]. Finally, despite the risks, the likelihood of suicide was low and researchers have argued that immigrant children and adolescents may escape local risk due to cultural values and supportive family environments [57, 58].

Our review uncovered one study related to sexual assault experienced by immigrant girls, with first generation black adolescent girls and sexually Hispanic girls being at increased risk in the U.S. [32]. Though this was the only study in our review documenting increased risk of sexual violence among specific subpopulations of immigrant adolescents, sexual violence and victimisation against women and girls is internationally acknowledged as a health, social, political, and human rights concern, particularly within precarious refugee or immigration contexts 
Table 2 Summary of Findings- Bullying, peer aggression, sexual violence and suicide among immigrant children and adolescents

\begin{tabular}{|c|c|c|c|}
\hline Outcome & Studies and Participants & Summary of Findings & $\begin{array}{l}\text { GRADEEstimate } \\
\text { ofcertainty } \\
\text { ofevidence }\end{array}$ \\
\hline Suicide attempts/ideation & $\begin{array}{l}8 \text { observational studies } \\
\text { Korean, Latin American, Jewish, } \\
\text { Russian, Suriname, Moroccan } \\
\text { and Turkish, Chinese }\end{array}$ & $\begin{array}{l}\text { First generation immigrant adolescents had lower suicide } \\
\text { attempt rates than non-immigrant adolescents and third } \\
\text { generation immigrant adolescents (RR 2.87; } 95 \% \text {, CI } \\
\text { 1.34-6.14) } \\
\text { Immigrant adolescents who are not living together with } \\
\text { their biological parents reported higher levels of life } \\
\text { stress and suicidal thoughts than their counterparts who } \\
\text { were living with parents }\end{array}$ & Low \\
\hline $\begin{array}{l}\text { Bullying, Peer } \\
\text { Aggression Sexual } \\
\text { violence and other } \\
\text { violence }\end{array}$ & $\begin{array}{l}10 \text { observational studies } \\
\text { Cambodian, Chinese Vietnamese, } \\
\text { Latin American, Laos, Asian } \\
\text { American, Filipino }\end{array}$ & $\begin{array}{l}\text { First generation and non-native English speaking } \\
\text { immigrants were more likely to report of being victim of } \\
\text { violence at school than native English speaker } \\
\text { counterparts. ( } p<0.001) \\
\text { Parent to child aggression was lower in first generation } \\
\text { immigrant families in US compared to White and Black } \\
\text { American families. } \\
\text { Refugee status and advanced parental age were associated } \\
\text { with increased parent to child aggression among South } \\
\text { East Asians }\end{array}$ & Low \\
\hline
\end{tabular}

[59-61]. The reasons for increased vulnerability are multiple and cross all components of their eco-system. For example, cultural tensions within families may constitute such vulnerability and increase the risk of victimisation for immigrant girls for several reasons including lack of appropriate sexual education on strategies to detect danger and self-protect for first generation immigrant girls. Risk may also increase in contexts where sexual harassment is silenced due to stigma and the resultant feelings of shame, self-condemnation, and distrust that constitute major barriers to disclosure [62]. In addition, the higher victimisation of black girls may be understood within a framework of racism.

Our findings reinforce previous studies demonstrating that most immigrant adolescents endure psychosocial stress when integrating into their new country. However, while data on risk would suggest poor mental health outcomes, our review found that this was largely not the case. This supports a large body of literature documenting an immigrant mental health paradox or advantage, whereby despite exposure to psychosocial and economic adversity, immigrant youth in Canada, the U.S., the U.K., and Australia generally have better mental health, compared to nonimmigrant youth [20-22, 63].

\section{Limitations}

There are important limitations to this review. First, data came from observational studies which cannot infer causality. The certainty of this evidence was low based on
GRADE appraisals. Second, we considered published research on adolescents and parents, but did not include research on teachers, religious and community group leaders and administrative officers who provide services for adolescents. Perspectives from these groups may be worth examining. Third, there is a need for more consistency in terminology related to immigrant status in order to track adolescents over time to study the impact of immigration on psychological outcomes [64].

Finally, our studies came from multiple countries and considered multiple immigration nationalities and there was also heterogeneity of outcomes. Although we could identify a few outlying ethnic- or country-specific effects, more are likely to be present. In some of the studies, immigrant subgroups (refugees and immigrants) and cultural groups (Asian, Latin American) were grouped together, and the data was not always disaggregated to look at potential equity issues during analysis. This heterogeneity and aggregation of outcomes reduced the certainty of our conclusions and negated any pooling of the data.

\section{Conclusions}

The findings of this review identified that adolescents from first generation non-native language speaking backgrounds (Chinese, Cambodian, Vietnamese, and Latin American) were more likely to experience victimization from bullying and peer aggression at school than later generation immigrants. Despite these challenges, most immigrant adolescents living with their biological parents had lower rates of 
suicidal ideation and suicide attempts compared to their non-immigrant and native-born or second- and third generation counterparts. Studies showed that in most cases, a supportive, cohesive (all members living together) family is associated with both less violence and less suicidal ideation.

Ongoing research is needed examining the challenges experienced by immigrant adolescents and their families, as well as the mediating and mitigating factors associated with these challenges. Research must continue to include ethnically diverse samples and different immigration statuses and other variables, and subgroup analyses are needed in order to better understand differences among and between groups. Further studies may also benefit from examining the vulnerability factors associated with increased risk of being bullied, and developing and assessing the effectiveness of programs aimed at prevention or intervention.

Acknowledgments The authors would like to acknowledge the expert librarian support of Tamara Radar. The authors of this paper would like to acknowledge the screening and data extraction work of Colin McCann, Eloise Douglas, and Bishwa Regmi. This research was funded by the Canadian Institute of Health Research synthesis competition and supported by the Canadian Institute of Child Health.

Open Access This article is distributed under the terms of the Creative Commons Attribution License which permits any use, distribution, and reproduction in any medium, provided the original author(s) and the source are credited.

\section{References}

1. Zimmerman C, Kiss L, Hossain M. Migration and health: a framework for 21st century policy-making. PLoS Med. 2011; 8:e1001034.

2. Koser K, Laczko F. World Migration Report 2010: The future of migration: Building capacities for change. International Organization for Migration; 2010.

3. Alink LR, Euser S, van Ijzendoorn MH, Bakermans-Kranenburg MJ. Is elevated risk of child maltreatment in immigrant families associated with socioeconomic status? Evidence from three sources. Int J Psychol. 2013;48:117-27.

4. World Health Organization. Health Topics. http://www.who.int/ topics/en/ (2014). Accessed 22 July 2014.

5. World Health Organization. How health systems can address health inequities linked to migration and ethnicity. Copenhagen: WHO Regional Office for Europe; 2010.

6. Qin DB, Way N, Rana M. The, "model minority" and their discontent: examining peer discrimination and harassment of Chinese American immigrant youth. New Dir Child Adolesc Dev. 2008;2008:27-42.

7. Hassan G, Rousseau C, Measham T, Lashley M. Caribbean and filipino adolescents' and parents' perceptions of parental authority, physical punishment, and cultural values and their relation to migratory characteristics. Can Ethn Stud. 2008;40(2):171-86.

8. Robben ACGM, Suárez-Orozco M, editors. Cultures under siege: collective violence and trauma. New York: Cambridge University Press; 2000.
9. Suarez-Orozco C. Afterword: understanding and serving the children of immigrants. Harvard Educ Rev. 2001;71:579-90.

10. Beiser M, Hou F, Hyman I, Tousignant M. Poverty, family process, and the mental health of immigrant children in Canada. Am J Public Health. 2002;92:220-7.

11. Chisolm DJ, Mulatu MS, Brown JR. Racial/ethnic disparities in the patterns of co-occurring mental health problems in adolescents in substance abuse treatment. J Subst Abuse Treat. 2009;37: 203-10.

12. Bellmore AD, Witkow MR, Graham S, Juvonen J. Beyond the individual: the impact of ethnic context and classroom behavioral norms on victims' adjustment. Dev Psychol. 2004;40:1159.

13. Borowsky IW, Taliaferro LA, McMorris BJ. Suicidal thinking and behavior among youth involved in verbal and social bullying: risk and protective factors. J Adolesc Health. 2013;53:S4-12.

14. Espelage DL, Holt MK. Suicidal ideation and school bullying experiences after controlling for depression and delinquency. J Adolesc Health. 2013;53:S27-31.

15. Karch DL, Logan J, McDaniel DD, Floyd CF, Vagi KJ. Precipitating circumstances of Suicide among youth aged 10-17 years by sex: data from the National Violent Death Reporting System, 16 States, 2005-2008. J Adolesc Health. 2013;53:S51-3.

16. Forero R, McLellan L, Rissel C, Bauman A. Bullying behaviour and psychosocial health among school students in New South Wales, Australia: cross sectional survey. BMJ. 1999;319:344.

17. Phalet K, Schonpflug U. Intergenerational transmission of collectivism and achievement values in two acculturation contexts the case of Turkish families in Germany and Turkish and Moroccan families in the Netherlands. J Cross Cult Psychol. 2001;32:186-201.

18. Choi Y, He M, Harachi TW. Intergenerational cultural dissonance, parent-child conflict and bonding, and youth problem behaviors among Vietnamese and Cambodian immigrant families. J Youth Adolesc. 2008;37:85-96.

19. McQueen A, Greg Getz J, Bray JH. Acculturation, substance use, and deviant behavior: examining separation and family conflict as mediators. Child Dev. 2003;74:1737-50.

20. Coll CG, Marks AK, editors. The immigrant paradox in children and adolescents: Is becoming American a developmental risk? Washington: American Pschological Association. ISBN: 978-14338-1053-4.

21. Reynaga-Abiko G. Review of The immigrant paradox in children and adolescents: Is becoming American a developmental risk? [Review of the book The immigrant paradox in children and adolescents: is becoming American a developmental risk? In Coll GC, Marks AK editors]. Cultur Divers Ethnic Minor Psychol. 2012;18(4):429-30. doi:10.1037/a0028424.

22. Marks AK, Ejesi K, Coll CG. Understanding the U.S. immigrant paradox in childhood and adolescence. Child Dev Perspect. 2014;8(2):59-64.

23. Higgins JP, Green S. Cochrane handbook for systematic reviews of interventions. 5th ed. Chichester: Wiley Online Library; 2008.

24. Wells GA, Shea B, O'Connell D, Peterson J, Welch V, Losos M et al. The Newcastle-Ottawa Scale (NOS) for assessing the quality of nonrandomised studies in meta-analyses. 2000. http:// www.ohri.ca/programs/clinical_epidemiology/oxford.asp.

25. Guyatt GH, Oxman AD, Vist G, et al. GRADE Guidelines: 4. Rating the quality of evidence -study limitations (risk of bias). J Clin Epidemiol. 2011;64:407-15.

26. Liberati A, Altman DG, Tetzlaff J, et al. The PRISMA statement for reporting systematic reviews and meta-analyses of studies that evaluate health care interventions: explanation and elaboration. Ann Intern Med. 2009;151:W-65.

27. Lau AS, Takeuchi DT, Alegria M. Parent-to-Child Aggression Among Asian American Parents: culture, Context, and Vulnerability. J Marriage Fam. 2006;68:1261-75. 
28. Le TN, Stockdale G. Acculturative dissonance, ethnic identity, and youth violence. Cultur Divers Ethnic Minor Psychol. 2008;14:1.

29. Spencer JH, Le TN. Parent refugee status, immigration stressors, and Southeast Asian youth violence. J Immigr Minor Health. 2006;8:359-68.

30. Peguero AA. Victimizing the Children of Immigrants Latino and Asian American Student Victimization. Youth Soc. 2009;41: 186-208.

31. Peguero AA. Is immigrant status relevant in school violence research? An analysis with Latino students. J Sch Health. 2008;78:397-404.

32. Molnar BE, Buka SL, Brennan RT, Holton JK, Earls F. A multilevel study of neighborhoods and parent-to-child physical aggression: results from the project on human development in Chicago neighborhoods. Child Maltreat. 2003;8:84-97.

33. Fuligni AJ. Authority, autonomy, and parent-adolescent conflict and cohesion: a study of adolescents from Mexican, Chinese, Filipino, and European backgrounds. Dev Psychol. 1998;34:782.

34. Juang LP, Alvarez AA. Discrimination and adjustment among Chinese American adolescents: family conflict and family cohesion as vulnerability and protective factors. Am J Public Health. 2010;100:2403.

35. Altschul I, Lee SJ. Direct and mediated effects of nativity and other indicators of acculturation on Hispanic mothers' use of physical aggression. Child Maltreat. 2011;16:262-74.

36. Park MS. The factors of child physical abuse in Korean immigrant families. Child Abuse Negl. 2001;25:945-58.

37. Decker MR, Raj A, Silverman JG. Sexual violence against adolescent girls influences of immigration and acculturation. Violence Against Women. 2007;13:498-513.

38. Pena JB, Wyman PA, Brown $\mathrm{CH}$, et al. Immigration generation status and its association with suicide attempts, substance use, and depressive symptoms among Latino adolescents in the USA. Prev Sci. 2008;9:299-310.

39. van Bergen DD, Eikelenboom M, Smit JH, van de Looij-Jansen P, Saharso S. Suicidal behavior and ethnicity of young females in Rotterdam, the Netherlands: rates and risk factors. Ethn Health. 2010;15:515-30.

40. Cho YB, Haslam N. Suicidal ideation and distress among immigrant adolescents: the role of acculturation, life stress, and social support. J Youth Adolesc. 2010;39:370-9.

41. Ponizovsky AM, Ritsner MS. Suicide ideation among recent immigrants to Israel from the former Soviet Union: an epidemiological survey of prevalence and risk factors. Suicide Life Threat Behav. 1999;29:376-92.

42. Ying Y, Han M. The longitudinal effect of intergenerational gap in acculturation on conflict and mental health in Southeast Asian American adolescents. Am J Orthopsychiatry. 2007;77:61-6.

43. Kim SY, Chen Q, Li J, Huang X, Moon UJ. Parent-Child acculturation, parenting, and adolescent depressive symptoms in Chinese immigrant families. J Fam Psychol. 2009;23:426.

44. Leschied A, Chiodo D, Nowicki E, Rodger S. Childhood predictors of adult criminality: a meta-analysis drawn from the prospective longitudinal literature. Can J Criminol. 2008;50: 435-67.

45. Acevedo-Garcia D, Almeida J. Special Issue introduction: place, migration and health. Soc Sci Med (1982). 2012;75:2055.
46. Acevedo-Garcia D, Sanchez-Vaznaugh EV, Viruell-Fuentes EA, Almeida J. Integrating social epidemiology into immigrant health research: a cross-national framework. Soc Sci Med. 2012;75:2060-8.

47. Lashley M, Hassan G, Maitra B. Cultural Consultation to Child Protection Services and Legal Settings. Heidelberg: Cultural Consultation, Springer; 2014. p. 269-90.

48. Verdugo RR. Safe Schools: theory, Data, and Practices. Educ Urban Soc. 1999;31:267-74.

49. Graham S. Peer victimization in school, exploring the ethnic context. Curr Dir Psychol Sci. 2006;15:317-21.

50. Juvonen J, Nishina A, Graham S. Peer harassment, psychological adjustment, and school functioning in early adolescence. J Educ Psychol. 2000;92:349.

51. Phinney JS, Ong A, Madden T. Cultural values and intergenerational value discrepancies in immigrant and non-immigrant families. Child Dev. 2000;71(2):528-39.

52. Portes A. Neoliberalism and the sociology of development: emerging trends and unanticipated facts. Popul Dev Rev. 1997; 23(2):228-55.

53. Berry JW. Immigration, acculturation and adaptation. Appl Psychol-Int Rev. 1997;46:5-68.

54. Fekkes M, Pijpers FI, Fredriks AM, Vogels T, Verloove-Vanhorick SP. Do bullied children get ill, or do ill children get bullied? A prospective cohort study on the relationship between bullying and health-related symptoms. Pediatrics. 2006;117:1568-74.

55. Vitoroulis I, Schneider BH. Bullying and victimization of immigrant youth: a literature review. Report submitted to CERIS. Working papers series (p. 1-65); 2009.

56. van Leeuwen N, Rodgers RRI, Chabrol H. The role of acculturation in suicidal ideation among second-generation immigrant adolescents in France. Transcultural Psychiatry. 2010;47:812-32.

57. Fuligni AJ. The academic achievement of adolescents from immigrant families: the role of family background, attitudes, and behavior. Child Dev. 1997;68:351-63.

58. Laaroussi, MV. Le familial au coeur de l'immigration: stratégies de citoyenneté des familles immigrantes au Québec et en France. Editions L'Harmattan, 2001.

59. Childress S. A meta-summary of qualitative findings on the lived experience among culturally diverse domestic violence survivors. Issues Ment Health Nurs. 2013;34(9):693-705.

60. Colucci E, Hassan G. Prevention of domestic violence against women and children in low income and middle income countries. Curr Opin Psychiatry. 2014;27(5):350-7.

61. Zhai F, Gao Q. Child maltreatment among Asian Americans: characteristics and explanatory framework. Child Maltreat. 2009; 14(2):207-24.

62. Hahm HC, Guterman NB. The emerging problem of physical child abuse in South Korea. Child Maltreat. 2001;6(2):169-79.

63. Provincial Council for Children's Health. Child Health System Indicators Summary. British Columbia. 2013.

64. Stevens GWJM, Vollebergh WAM. Mental health in migrant children. J Child Psychol Psychiatry. 2008;49(3):276-94.

65. van Bergen DD, Smit JH, van Balkom AJ, van Ameijden E, Saharso S. Suicidal ideation in ethnic minority and majority adolescents in Utrecht, the Netherlands. Crisis. 2008;29(4):202-8. 